\title{
Mechanization Problems Universal
}

Canada's forestry profession can still learn a great deal about forest management and logging practices, according to Ross Silversides, who recently rcturned from a lecture course in Sweden.

Mr. Silversides who is woodlands development engineer for Abitibi Power \& Paper Co. Ltd., was the only North American professional forester to lecture to representatives of the forestry profession who came from 15 European countries, including Russia.

The conference, a course on mechanized forest operations, was held at Farnabruk, about 100 miles west of Stockholm. It was sponsored by the U.N.'s Food and Agricultural Organization and the Economic Council of Europe along with the International Labor Organization.

Silversides lectured on mechanical logging operations carried out in eastern North American forests embracing woods labor, training methods, time and methods study, cutting, forwarding, hauling, skidding and the various types of mechanical equipment used.

He said the Scandinavian countries are differently mechanized than in Canada in woods operations since they more closely complement the agricultural cycle, and for this reason utilize much of the farm equipment with certain modifications.

He said he discovered during the lecture conference that problems in logging operations appear to be universal. The development and application of machines that would reduce logging costs appeared to be the greatest single problem faced by all countries' foresters.

\section{Complete Sets \\ of}

1959 ANNUAL MEETING PAPERS

can be obtained from:

T. P. Decie

B.C. Forest Service

Prince George, B.C.

Cost $\$ 5.00$ per set.

Space may not permit full publication

in The Forestry Chronicle. 